\title{
Güncel Türkçe Sözlük'te yer alan acı maddesinin eş anlamlılık açıSından incelenmesi
}

\section{Melike SOMUNCU'}

\begin{abstract}
APA: Somuncu, M. (2020). Güncel Türkçe Sözlük'te yer alan acı maddesinin eș anlamlılık açısından incelenmesi. RumeliDE Dil ve Edebiyat Araşttrmalar Dergisi, (20), 202-217. DOI: 10.2900o/rumelide.791145.
\end{abstract}

\section{$\ddot{\mathbf{O} z}$}

Dilbilim çalışmalarının önemli, aynı zamanda tartışmalı bir konusu olan eş anlamlılık kavramı üzerine yapılan araştırmalar son yıllarda hem hız kazanmış hem de farklı bir boyuta ulaşmıştır. Her kelimenin mutlaka diğer kelimelerden ayrılan bir anlamı bulunmaktadır. Her duygunun ve anlamın da mutlaka onu karşılayan bir kelimesi vardır. Bu yüzden mutlak eş anlamlılık çok zor bir düzlemdir. Türkiye Türkçesi bağlamında bu iki tutum çerçevesinde mutlak eş anlamlı kelime bulmak da zordur. Bu çalışmada Güncel Türkçe Sözlük esasında incelenen acı kelimesinin eş anlamlılık derecesi, bu maddenin ifade alanında yer alan ızdırap, üzüntü, keder ve elem anlamları bağlamında incelenmiştir. Daha sonra bu dil birimlerinin anlam sınırında yer alan gam, teessür, tasa, dert ve sıkıntı kelimeleri de ele alınmıştır. Ele alınan bütün kelimelerin eş anlamlılık dereceleri sözlüksel, kavramsal ve atasözü / deyim bağlamında sunulmuştur. Elde edilen veriler eş anlamlılığın bir ölçüm meselesi olması fikrinden yola çıkılarak irdelenmiştir. Bu ölçüm meselesine bir derecelendirme ölçütü getirilerek eş anlamlılığa yeni bir bakış açısı sunulmaya çalışılmıştır. Derecelendirmede birinci dereceden yakın eş anlamlılık, ikinci dereceden yakın eş anlamlılık şeklinde bir ölçüm esas alınmıştır. Böylece acı maddesi bağlamında söz konusu dil birimlerinin eş anlamlılık dereceleri belirlenmiştir. Ayrıca Güncel Türkçe Sözlük'ün hem madde başı anlamlarına hem de atasözü / deyim kısımlarına eklenmesi tavsiye edilen dil birimleri ifade edilerek Güncel Türkçe Sözlük'e katkıda bulunulmuştur.

Anahtar kelimeler: Eş anlam, yakın anlam, derecelendirme, acı

\section{Investigation of the words pain in terms of synonym in The Current Dictionary Turkish Glossary}

\begin{abstract}
Research on the concept of synonym, which is an important and controversial subject of linguistics, has gained momentum and reached a different dimension in recent years. Every emotion and meaning has a word that definitely meets it. So absolute synonym is a very difficult plane. Turkey in the Turkish context within the framework of these two attitudes are hard to find absolute synonyms. In this study, the degree of synonymity of the word pain, which is examined on the basis of the Current Turkish Dictionary, has examined the meanings of suffering, sadness, grief and sorrow in the expression field of this article. Later, the words of scale, apprehension, concern, trouble and distress, which are within the meaning boundary of these language units, were also discussed. The synonym degrees of all the words discussed are presented in the context of lexicography, conceptual and proverb / idiom. Language units that are recommended to be included in both the meanings of the
\end{abstract}

Dr. Öğr. Üyesi, Siirt Üniversitesi, Fen Edebiyat Fakültesi, Türk Dili ve Edebiyatı Bölümü (Siirt, Türkiye) melike.somuncu@siirt.edu.tr, ORCID ID: oooo-0002-9101-3012 [Makale kayıt tarihi: 16.05.2020-kabul tarihi: 20.09.2020; DOI: 10.29000/rumelide.791145] 
article and the proverb / phrase sections of the Turkish Dictionary are expressed. The data obtained were examined based on the idea that synonym is a matter of measurement. By introducing a rating criterion to this measurement issue, a new perspective on synonym was tried to be presented. The rating is based on first degree close synonym, and second degree close synonym. Thus, in the context of the bitter substance, the synonym degrees of the said language units were determined and some contributions were made to the Current Turkish Dictionary.

Keywords: Synonyms, close meaning, classification, pain

\section{Giriş}

Dilbilim çalışmalarının önemli aynı zamanda tartışmalı bir konusu olan eş anlamlılık kavramı üzerine yapılan araştırmalar son yıllarda hem hız kazanmış hem de farklı bir boyuta ulaşmıştır. Son yıllarda eş anlamlılık, özellikle bilişimsel dil biliminin (computational linguistics) konusu hâline gelmiştir. Bu duruma en güzel örnek olarak İngilizcedeki kelimelerinin bilişsel eş anlamllık setlerinin ve kelimeler arasındaki ilişkilerin belirlenmesi için Princeton Üniversitesi tarafindan oluşturulan WordNet’i göstermek mümkündür (http://wordnet.princeton.edu) (Pilten, 2008: 13). Bilim insanlarının eş anlamlılık kavramı ile ilgili farklı görüşleri bulunmaktadır. İki ya da daha çok sayıdaki göstergenin aynı anlama gelmesi ve aynı göstergelerin aynı gösterilenleri belirtmesi eş anlamlılı̆̆ın tanımı içinde yer almaktadır (Vardar, 2007: 94). Eş anlamlılıkta tam bir özdeşliğin olmasından ziyade anlamca yakınlı̆̆ın ön sırada olması, aynı bağlam içerisinde birbirinin yerine tam olarak kullanılabilecek göstergelerin az sayıda bulunması söz konusudur (Vardar, 2007: 96). Eş anlamlılık, anlam ve işlev yönünden birbirinin aynısı veya benzeri olan dil birimlerinin ilişkisi olarak da görülür. Ama anlam bakımından birbirleri ile tam olarak benzeşen veya örtüşen kelimelerin olmaması ve eş anlamlı kelimelerin anlam açısından benzer ama birini diğerinden ayıran bir ayrıntıya da sahip olduğu kabul gören görüşlerdendir (Karaağaç, 2013: 373-375). Eş anlamlı kelimelerin anlam açısından aynı, yakın veya benzer olmaları dışında bir de aynı kelime türünde olmaları gerekir. Farklı kelime türünden olan dil birimleri eş anlamlı olmamaktadır (Karaağaç, 2013: 373).

Genel dilbilimde anlamca birbirinin tam benzeri veya dengi çok az kelime bulunur. "Bir kavrama bir sözcük ilkesi benimsendikten sonra, birden fazla sözcü̆üun aynı kavramı yansıtması düşünülemez" (Aksan, 1978: 72) fikri kelimelerin eş anlamlı olmasından ziyade yakın anlamlı olmasını da kuvvetlendirmektedir. Eş anlamlılıkta sosyal çerçevede ve dil mecrasında bazı kelimelerde yer alan anlam inceliklerinin zamanla gölgelenerek anlam yönünden birbirlerine yaklaşmaları söz konusudur (Korkmaz, 2007: 85-87). Kelime veya cümlelerin özdeş anlamda bulunmaları şeklinde tanımı bulunan eş anlamlılığın, aslında hiçbir kelime veya tümcede söz konusu olamayacağı kanaati yaygındır. İki kelime bütün bağlamlarda birbirinin yerine kullanılabilmesi durumunda ancak eş anlamlılı̆̆ın olabileceği de savunulmaktadır (İmer vd, 2011: 118). Esasen iki farklı gösterge bütün olarak aynı anlama gelemez. Dil ögelerini yakın anlamlı kelimeler olarak tanımlamak en doğru olandır. "Dilin ifadeyi en basit ve en rahat söyleme özelliğinden dolayı hiçbir dil başlangıçta bir nesne, durum veya olayı işaret edebilmek için birden fazla sözcüğe ihtiyaç duymaz. Bu nedenle birbirinin tam aynı, eşi anlamına gelen birden fazla yerli sözcüğün bulunmadığı” (Aksan, 2006: 190) genel kabullerdendir.

Ullmann (1959: 108-110), tam eş anlamlılığın çok nadir görüldüğünü, tam eş anlamlılığın oluşabilmesi için anlam belirsizliği ve duygusal anlamlandırma gibi iki önemli engelin olduğunu, bilişsel ve duyusal anlamda en ufak bir ayrım olmaksızın bir bağlamda birbirinin yerine kullanılabilen kelimelerin eş anlamlı olarak anlamlandırılabileceğini savunmaktadır. Eş anlamlılığı salt eş anlamlılık (Pure 
synonyms) ve sözde eş anlamlılık (Pseudo-synonyms or homoionyms) olarak ikiye ayıran Ullmann, salt eş anlamlılıkta kelimelerin duyusal ve duyuşsal değerde birlikte var olabilme ve birbiri yerine kullanılabilme durumunun olduğunu savunmaktadır. Sözde eş anlamlllkta ise iki durumun olduğunu, bunlardan birincisinin kelimelerin bazı bağlamlarda birlikte var olabilip birbiri yerine kullanılabilmesi olarak açıklamaktadır. Yalnız bu durum tüm bağlamlarda geçerli değildir. İkincisini ise bilişsel açıdan birlikte var olma ve birbirinin yerine kullanılabilmesi olarak açıklamaktadır. Fakat bunda da duyusal ve çağrışımsal açılardan bir geçerliliğ̈in olmadığını ifade etmektedir. Çünkü herhangi iki anlamın bir arada olabileceğini kanıtlamak ve göstermek oldukça zordur.

Gündelik kullanımlar içinde farklı biçimler sunan ama benzer veya özdeş olan kelimeler arasında biçimbilimsel ve söz dizimsel konumu ortaklaşa paylaşan kelimeleri eş anlamlılık olarak tanımlayan Tamba - Mecz (1998: 94)'in görüşüne yakın bir görüş sergileyen Murphy ise eş anlamlılıkta bağlam, kelimelerin birbiri yerine kullanılması ve anlam benzerliğin olması gerektiğini vurgular ve iki kelimenin tam olarak benzeşmesini eş anlamlılık olarak görmektedir (Murphy, 2013: 81-93). Guiraud'a göre "anlam değişir: Çünkü çağrışımlardan biri ikincildir (bağlamsal anlam, anlatımsal anlam, toplumsal değer) ve yavaş yavaş temel anlama doğru kayarak onun yerini alır; anlam, evrim geçirir”, çağrışımlar kelimelerde çok anlamlılı̆̆a neden olmaktadır (Guiraud, 1999: 67). İdeal olan her dilde her kelimenin tek anlamlı olmasıdır. Fakat bu tam olarak mümkün değildir. İki ya da daha çok biçimin aynı anlam düzlemini çağrıştırması olarak da tanımlanan eş anlamlılı̆̆ "bir tümce S1 başka bir tümceyi, S2'yi usa getirirse ve bunun tersi de doğruysa, S1 ve S2 eşdeğerlidir. (...) iki eşdeğerli tümcenin sözdizimi, yapıları aynı ise ve birbirinden yalnızca birinde $\mathrm{x}$ sözcüğü, ötekinde de y sözcüğü bulunması yönünden ayrilıyorlarsa, x ile y eşanlamlıdır." şeklinde örneklendiren Lyons, eş anlamlılıkta esas nokta olarak 'olağan değiştirilebilirlik ve bağlam / bağıntı'yı kullanmaktadır (Lyons, 1983: 363-402). Lyons, iki temel eş anlamlılık türünden söz etmekte ve eş anlamlılık terimini derecelendirmektedir. Bazı bağlamlarda hem bilişsel hem de duygusal anlam eş değerliği için "tam eş anlamlılık", bütün anlamlarında / bağlamlarında birbirinin yerine kullanılabilen eş anlamlı kelimeler için ise "bütüncül eş anlamlılık" terimlerini kullanır ve dört çeşit eş anlamllıktan bahsetmektedir:

1.Tam ve bütüncül eş anlamllık,

2. Tam ama bütüncül olmayan eş anlamllılk,

3. Tam olmayan ama bütüncül olan eş anlamlılık,

4. Tam ve bütüncül olmayan eş anlamlllık (Lyons, 1983: 399-400).

Lyons (1983: 401)'a göre tam ve bütüncül eş anlamlı kelimelerin bir dildeki sayısı oldukça azdır. Tam eş anlamlılıktan kasıt, bilişsel ve duygusal eş değerlilik, bütüncül eş anlamlılık ise birbiri yerine geçebilen kelimelerde denkliktir. Eş anlamllıkta kelimenin bağlamına, türüne ve derecesine göre farklı türleri bulunmaktadır.

Cruse, eş anlamlılığı bütünsel, bilişsel ve yakın eş anlamlılık olarak değerlendirir ve eş anlamlılığın derecelerinin olması gerektiğinden bahsetmektedir. Bütünsel eş anlamllhkta, iki kelimenin tüm anlamlarının bütün bağlamlarda yer değiştirebilmesi ve bilişsel / duygusal anlamda da bu kelimelerin tam özdeşleşmesidir. Bilişsel eş anlamlılıkta ise bir kelimenin diğer kelimenin yerine konması sonucunda cümlelerin anlamlarının aynı olması ve cümlede yer alan birden çok ögenin eş anlamlı olmasıdır. Yakın eş anlamlılıkta ise anlamca daha az ya da daha çok benzer olan ama aynı veya özdeş olmayan durum söz konusudur. Temelde farklı koşulları olan cümleleri olması bakımından yakın eş anlamlılık, bütünsel ve bilişsel eş anlamlllıktan ayrılır (Doğan, 2011: 81-82). Güncel Türkçe Sözlük sınırında ele alınan acı maddesinin ilişkili olduğu diğer anlamlar arasındaki bağlantı için yakın eş 
anlamlllık teriminin ve durumunun daha uygun olduğu görülmektedir. Çünkü bütünsel eş anlaml kelime bulmak çok zor iken bilişsel eş anlamlı kelime bulmak nispeten daha kolaydır. Eş anlamlı kelimelerin aynılığı veya özdeşliği bilişsel eş anlamlllk çerçevesi içinde iken sözlüksel birimlerin anlamsal yakınlı̆̆ veya benzerliği ise yakın eş anlamlılık çerçevesi içerisindedir (Doğan, 2011: 81-85). Cruse'a göre eş anlamlılığın üç türü bulunmaktadır. Birincisi mutlak eş anlamlılık, ikincisi önermesel eş anlamlılık, üçüncüsü yakın eş anlamlılık. Mutlak Eş Anlamlılı (Absolute Synonymy): Anlamın tam özdeşliğini ifade etmekte ve mutlak eş anlamlılığın oluşabilmesi için sözcüklerin bütün bağlamlarda özdeş olması gerekmektedir. Önermesel Eş Anlamllhk (Propositional Synonymy): Bu türde kelimeler aynı anlamı ifade eder, bağlamda birbirinin yerine geçer ama tam özdeşlik yoktur. Fiddle (keman) ve violin (keman) örnekleri eş anlamlı çiftlerdir. Burada konuşura bağlı olarak bu iki kelimenin anlam derecesi değişmektedir. Türkçede hepatit ve sarılık kelimeleri birbirinin yerine kullanılabilir. Ancak "hepatit" kelimesi daha özel ve dar bir çevrede kullanılır aynı zamanda daha profesyonel bir kullanım alanı vardır. "Sarılık" ise, daha yaygındır ve günlük bir terimdir. Bu sebepten ötürü her iki kelime özdeş olmaktan uzaktır. Yakın Eş Anlamlılk (Near-synonymy): Anlamları nispeten yakın olan sözcüklerin durumunu ifade etmektedir, bu yakınlığın belli belirsiz alt sınırları vardır. Sözlüklerde açılama / tanımlama amaçlı kullanılan yakın anlamlı sözcükler bu türe girer. Benzerlikleri farklılıklarından daha belirgindir (Cruse, 2000: 156-160). Güncel Türkçe Sözlük sınırında ele alınan acı maddesinin ilişkili olduğu diğer anlamlar arasındaki bağlantı için yakın eş anlamlılık teriminin ve durumunun daha uygun olduğu görülmektedir. Eş anlamlı kelimelerin semantik özellikleri aynıdır ama çevresel özellikleri farklıdır. Eş anlamlılıkta birbirinin yerine geçme ve bağlamsal açıdan benzerlik temel unsurdur. Eş anlamlılık için anlam açısından aynı yerine anlam açısından benzer kelimeler demek daha doğrudur.

Eş anlamlılıktaki temel sorun anlamın derecesi ve türüdür. Eş anlamlılık esasen bir ölçüm meselesidir. Eş anlamlılık kategorisinde yer alan kelimelerden bazıları daha fazla eş anlamlıdır bu da bir tür eş anlamlılık ölçeği ihtimalini doğurmaktadır. Mutlak eş anlamlılık anlamca tam olarak özdeşlik bildirmektedir (Cruse, 1986: 267-269). Mutlak eş anlamlılı̆̆ın olabilmesi için eş dizimlilik çok önemli bir noktadır. Eş dizimlilik noktasında mutlak eş anlamlı kelimelerin birbirlerinin yerine kullanımı söz konusudur. Bir dilde elbette mutlak eş anlamlılık vardır. Ama bu çalışmada ele alınan acı maddesi bağlamında mutlak eş anlamlı kelimeye rastlanmamıştır. Çünkü eş dizimsel sıralamada kelimelerin bulunduğu bağlamsal bir bağ vardır. Eş anlamlılıkta bu bağlamsal bağ birbirinin yerine geçebilmeyi gerektirir. Bu durum ancak mutlak eş anlamlllıkta bulunmaktadır. Fakat hem söylem hem bağlam anlamında birebir örtüşmeyi sağlayan kelime sayısı oldukça sınırlıdır. Bu yüzden eş anlamlılıktan ziyade anlamsal ve kavramsal örtüşmeyi barındıran kelimeler arasında dereceli yakın eş anlamlllık olduğunu söylemek daha doğru olur. Derecelendirme ise anlamsal / kavramsal yapı ile eş dizimlilik düzlemindeki yakınlık belirleyicidir.

\section{Çalışmanın amacı}

Eş anlamlı kabul edilen kelimeler her zaman birbirinin yerine kullanılamaz. Bazı kelimeler sadece belirli şartlar altında birbirinin yerine geçebilir. Eş anlamlılığın derecesinin belirlenmesinde eş dizimsel yapı önemli bir ölçüt olmaktadır. Bu ölçüt dışında çağrışımsal anlam ve kullanım faktörü de önemli diğer ölçütlerdendir. Bu görüş çerçevesinde çalışmanın amacı, Güncel Türkçe Sözlük’te yer alan acı maddesinin nasıl ele alındığını göstermek, acı maddesi ile ilişkili diğer kelimelerin eş anlamlılık derecesini belirlemek ve Güncel Türkçe Sözlük'e acı maddesi bağlamında katkıda bulunmaktır. 


\section{Çalışmanın sınırlılı̆̆ı}

Güncel Türkçe Sözlük'te yer alan acı maddesi ele alınmıştır. Bu madde ile doğrudan ilişkisi olan, genel olarak eş anlamlılık düzleminde yer alan ızdirap, üzüntü, keder ve elem kelimeleri ve bu kelimelerin anlam ve kavram alanında yer alan sıkıntı, gam, teessür, dert ve tasa maddeleri de incelenmiştir.

\section{Çalışmanın yöntemi}

Güncel Türkçe Sözlük özelinde acı maddesinin bağlantılı olduğu ızdırap, üzüntü, keder ve elem kelimelerinin incelendiği bu çalışmada, acı maddesi merkez konumdadır. Bu merkeze bağlı olarak anlamsal yönü incelenen kelimeler ve bu kelimeler ile bağlantılı diğer kelimeler de ele alınmıştır. Bu yüzden ızdırap maddesinin anlam alanında yer alan sıkıntı, üzüntü maddesinin anlam alanında yer alan gam ve teessür, keder maddesinin anlam alanında yer alan dert, tasa maddeleri de act kelimesi merkezinde incelenmiştir. Elde edilen veriler eş anlamlılığın bir ölçüm meselesi olması fikrinden yola çlkılarak irdelenmiştir. Bu ölçüm meselesine derecelendirme ölçütü getirilerek eş anlamlılığa yeni bir bakış açısı sunulmaya çalışılmıştır. Derecelendirme ölçütünde birinci dereceden yakın eş anlamlılık, ikinci dereceden yakın eş anlamlılık şeklinde bir ayrıma gidilmiştir. Birinci dereceden yakın eş anlamlılık kapsamına hem sözlük anlamı hem kavram alanı aynı ve atasözü / deyimlerde de benzerlik veya aynılık ihtiva eden kelimeler girmektedir. İkinci dereceden yakın eş anlamlılk kapsamına ise ya sözlük ve kavram alanı ya da atasözü / deyimlerde benzerlik noktası bulunan kelimeler girmektedir.

\section{Verilerin değerlendirilmesi ${ }^{2}$}

\section{Acı maddesinin anlam alanında bulunan kelimelerin eş anlamlılık dereceleri}

Bir dilin yazı dili olarak işlek kullanılması ve verilen ürün sayısına paralel olarak dildeki eş anlamlılık sayısını arttırmaktadır. Bu işleklik aralarında çok az ayrım olan yeni soyut ve somut kavramlar ortaya çıkarır. Bugün İngilizce, Almanca gibi pek çok kültür dilinde de eş anlamlı kelime sayısı çoktur. Türkçe de bir kültür dilidir ve Türkçede eş anlamlı kelime sayısı azımsanmayacak düzeydedir (Aksan, 1996: 68). Türkçede eş anlamlı kelimelerdeki artışın bir diğer nedeni ise yabancı kelimelerin dile çok çabuk yer edinip kullanılır hâle gelmesi ile ilişkilendirilebilir. Acı kelimesinin Türkçede üzüntü, diğer dillerde ise ızdırap, keder ve elem kelimeleri ile eş düzlemde olduğu görülmektedir. Yalnız tam eş anlamlı gibi görünen bu kelimeler bağlam içinde birbirinden ayrılan yönleri bulunmaktadır. Bu ayrılan yönler hem sözlüksel hem kavramsal hem de atasözü / deyim gibi kullanım sahasında kendini göstermektedir.

Tablo 1: Acı kelimesinin GTS'deki anlam siralaması:

Acı maddesinin GTS'de yedi anlamı bulunmaktadır3:

\begin{tabular}{|l|l|l|}
\hline \multirow{4}{*}{ Acı } & 1. & Bazı maddelerin dilde bıraktı̆̆ı yakıcı duyu, tatlı karşıtı. (isim) \\
\cline { 2 - 3 } & 2. & Tadı bu nitelikte olan. (sıfat) \\
\cline { 2 - 3 } & 3. & Herhangi bir dış etken dolayısıyla duyulan rahatsızlık, ızdırap. (isim) \\
\cline { 2 - 3 } & 4. & $\begin{array}{l}\text { Ölüm, yangın, deprem vb. olayların yarattı̆̆ı üzüntü, keder, elem. (isim / } \\
\text { mecaz) }\end{array}$ \\
\cline { 2 - 3 } & 5. & Çarpıcı, göz alıcı (renk). (sıfat) \\
\hline
\end{tabular}

Güncel Türkçe Sözlük bu bölümde GTS olarak kısaltılmıştır. İncelenen kelimelerin hepsi şu adresten alınmıştır: Güncel
Türkçe Sözlük, https://sozluk.gov.tr/, 28.05.2020 $3 \quad$ Kelimenin 1., 2. ve 5. anlamı konunun kapsamı dışındadır. 


\begin{tabular}{|l|l|l|}
\hline & 6. & Keskin, şiddetli. (sıfat /mecaz) \\
\cline { 2 - 3 } & 7. & Krrıcı, üzücü, incitici, dokunaklı, kötü. (sıfat /mecaz) \\
\hline
\end{tabular}

Acı maddesinin üçüncü anlamında ızdırap ifadesi yer almaktadır. Acı maddesinin duygu içeren ilk anlamı bu durumda ızdırap olarak kayda geçmiştir.

Tablo 2: Izdırap kelimesinin GTS'deki anlam sıralaması:

Izdırap maddesi incelendiğinde GTS'de sadece bir anlamının bulunduğu görülmektedir:

\begin{tabular}{|l|l|l|l}
\hline Izdırap (Arapça) & 1. & Acı, üzüntü, sıkıntı, keder. (isim) \\
\hline
\end{tabular}

Izdırap maddesi duygu ifadesi kapsamında acı, üzüntü, sıkıntı ve keder ile açıklanmaktadır. Alfabetik bir sıra ile verilmediğine göre GTS'de kabul edilen görüş, ıdırap maddesinin de ilk duygu ifadesinin acı olmasidır.

Her iki kelimenin eş düzlemde ve deyim içinde kullanımı GTS'de şöyle sunulmuştur:

Acr çekmek (veya duymak): 1. Ağrı, sızı duymak. 2. Üzülmek, üzüntü içinde kalmak: Izdırap çekmek: Ăgrı ve acı içinde kıvranmak, aşırı derecede üzülmek.

Görüldüğü üzere her iki kelime de çekmek yardımcı fiili ile çekimlenmiştir. Acı çekmek deyiminin ilk anlamı fiziksel bir acı veya ağrıyı ifade etmektedir. Acı kelimesinin ilk duygu anlamı ise üzüntü ve üzülmek dil birimleri sunulmuştur. Izdırap çekmek deyiminin esasen acı çekmek deyiminde olduğu gibi iki anlamı vardır. GTS'de bu maddenin de acı çekmek deyimdeki gibi iki ayrı maddede sunulması gerekmektedir: Birinci anlam, ağrı ve acı içinde kıvranmak. Bu anlam fiziksel bir acı veya ağrıyı ifade etmektedir. İkinci anlamda ise üzülmek dil birimi ile ifade edilen duygu aşırı pekiştirme zarfı ile sunulmuştur. Bu durumda acı ve ızdırap kelimelerinin denk anlama sahip olmadıkları görülmektedir. Izdırapta hissedilen olumsuz duygu daha üst düzeyde iken acıda hissedilen olumsuz duygunun derecesi ızdıraba göre daha düşüktür. Yabancı dillerden Türkçeye giren kelimeler bütüncül değil, parçalı eş anlamlılık oluşturmaktadırlar. Hiçbir zaman Türkçe bir kelime ile yabancı dildeki bir kelime mutlak bir eş anlamlılık gösteremezler. Bu tür kelimeler arasında ancak yakın anlamlılı söz konusudur (Demirezen, 1991: 133-138). Ayrıca Türkçe bir kelimeye karşılık olarak yabancı bir dilden alınan sözcük de her cümlede anlam bakımından Türkçe kelimenin eş anlamlısı olarak kullanılamaz (Hatipoğlu, 1970: 9). Acı ile ızdırap kelimelerinin kullanım ve kavram sahasına göre birinci dereceden yakın eş anlamlı kelimeler sınıfına dâhil etmek mümkündür. Çünkü her iki kelime bağlamda farklı anlam derecesine sahip olsalar da hem sözlüksel yakınlık (her iki kelimenin de paralel anlamı bulunmaktadır) hem de eş dizimsel yakınlık birinci dereceden yakın eş anlamlı kelimeler sınıfına dâhil edilmeyi gerektirmektedir.

Acı maddesinin dördüncü anlamında ölüm, yangın, deprem vb. olayların yarattığ üzüntü, keder, elem ifadeleri yer almaktadır. Bu maddenin anlam kapsamında yer alan üzüntü kelimesi incelendiğinde GTS'de üzüntü maddesinin şöyle anlamlandırıldığı görülmektedir:

Tablo 3: Üzüntü kelimesinin GTS'deki anlam sıralaması:

\begin{tabular}{|l|l|l|}
\hline Üzüntü & 1. & Olması istenilmeyen olaylardan doğan ruh tedirginliği, gam (I), teessür. (isim) \\
\hline
\end{tabular}


Üzüntü maddesinin anlamı GTS'de sadece bir karşlıkta ifade alanı bulmuştur. Görüldüğü üzere acı kelimesinin dördüncü anlamında üzüntü ifadesi yer alırken bu anlamın içinde acı ifadesi yer almamıştır. Acı kelimesinin yer aldığı deyimler incelendiğinde şu deyimlerin hepsinde üzüntü ifadesinin yer aldığı görülmektedir:

Acr gelmek: Dokunmak, kurmak, üzmek.

Acı vermek: Birinin üzülmesine sebep olmak, incitmek.

Acssma dayanamamak: Bir kimse, bir yakınınn ölümünden, kaybından büyük üzüntü duymak.

Actsin almak: Sıkıntısın, üzüntüsünü azaltmak.

Acısını çekmek: Yapılan yanlış bir işin doğurduğu sıkıntı ve üzüntü içinde bulunmak.

Üzüntü kelimesinin anlam sınırlılığı kapsamında GTS’ye acı kelimesi de eklenmelidir. Çünkü acı ile üzüntü kelimeleri arasında söylem ve bağlam içinde bir yakınlık ve sözlüksel bir örtüşme söz konusudur. Elbette acı gelmek deyiminde kullanılan acı kelimesi yerine üzüntü kelimesi getirildiğinde tam bir denklik vardır demek doğru değildir. Zaten eş anlamlı kelimeler arasında anlam eşitliği bütünüyle göreceli olup matematiksel bir eşitlik mümkün değildir. Her zaman, her anlamda ve her yerde bu kelimeler eş değerde olamazlar. Tamamen aynı gibi gözüken anlamca çok yakın kelimeler arasında bile çok küçük olsa da farklar bulunur (Hatipoğlu, 1970: 9). Üzüntü maddesinin deyim içinde kullanımı GTS'de şöyledir:

Üzüntü vermek: Tedirginlik yaratmak, sıkıntı ve huzursuzluğa yol açmak.

Her ne kadar üzüntü vermek ile acı vermek deyimleri arasında sözcüksel olarak GTS'de bir bağlam verilmemiş ve gösterilmemiş olsa da acı ve üzüntü maddeleri arasında paralel bağlamsal ilişki vardır. Acı kelimesinin duygu düzleminde daha derinden hissedilen olumsuz hissiyat vardır ve bu hissiyatın süresi daha uzun, varlığı daha kalıcıdır. Üzüntü kelimesinde hissedilen olumsuz hissiyatta ise acıya nazaran daha yüzeysel bir durum söz konusudur. Üzüntüdeki olumsuz hissiyatın acıya göre süresi daha kısadır, varlığı değişken ve geçicidir. Bu farklar söylem ve bağlamda kendini gösterir ama paralel düzlem her iki kelimeyi birinci dereceden yakın eş anlamlı kelimeler sınıfına dâhil etmektedir.

Tablo 4: Keder kelimesinin GTS'deki anlam sıralaması:

Acı maddesinin anlam kapsamında yer alan keder kelimesi incelendiğinde GTS'de keder maddesinin şöyle anlamlandırıldı̆̆ı görülmektedir:

\begin{tabular}{|l|l|l|}
\hline Keder (Arapça) & 1. & Acı, üzüntü, dert, sıkıntı, ızdırap, tasa. (isim) \\
\hline
\end{tabular}

Keder maddesinin GTS'de bir anlamı bulunmaktadır. Bu maddenin ilk anlamında acı ifadesi bulunurken, acı maddesinin dördüncü anlamında keder yer almaktadır. Uygunluk analizinde eş anlamlılığın derecesi, anlam grupları, kelimelerin cümle içindeki görevi ve gramer kategorilerine göre sinıflandırma ve karşılaştırma yapılarak tespit edilmektedir (Partington, 1998, aktaran Pilten, 2008: xvii ). Bu analiz bağlamında gramer kategorisi kelimelerin anlam analizinde önemli olduğu görülmektedir. Acı maddesinin dördüncü anlamında bu ifadelerin gramer sınırında isim ve mecaz 
olarak kullanım sahasına sahiptir. Keder maddesinin gramer sınırında bu durum sadece isim olarak nitelendirilmiştir. Maddenin gramer sınırına mecaz da eklenmelidir.

Ayrıca keder kelimesinin yer aldığı deyimler GTS’de şöyle verilmiştir.

Keder çekmek: Acı duymak, ızdırap çekmek.

Keder vermek: Üzüntü vermek, kederlendirmek, tasalandırmak.

GTS'de verilen keder çekmek deyimi acı çekmek ve ızdırap çekmek deyimleri ile aynı anlamda sunulmuştur:

Acr çekmek (veya duymak): 1. Ağrı, sızı duymak. 2. Üzülmek, üzüntü içinde kalmak: Izdırap çekmek: Ağrı ve acı içinde kıvranmak, aşırı derecede üzülmek.

Sözlüksel parçacıkların dizisel ilişkisi, aynı kategoriye sahip belli bir gramer ve leksikal bağlamda birbirinin yerine geçebilen kelimeleri kapsar. Ayrıca sözlüksel parçacıkların dizimsel ilişkisi bir kelimenin diğer kelimeler ile bir araya gelebilme yeteneğiyle de doğrudan ilişkilidir (Firth, 1957: 196198). Bu durum Gökalp’ın şu sözleri ile de açıllanabilir:

"Halk, Arapça ve Farsçadan bir kelime aldığında onun eş anlamlısı olan kelimeyi Türkçeden atar. Bu şekilde Türkçede eş anlamlı kelimeler kalmaz. Bazen Arapça ve Farsça kelimelerin yanında Türkçelerinin de korunduğu görülmektedir. Ancak, "Böyle bir hâl vukuunda da yine müteradif kelimeler vücuda gelmez. Çünkü ya Arapçadan ve Acemceden alınan kelimenin yahut eski Türkçe kelimenin manâsında bir tagayyür husûle gelerek, ikisi arasındaki müteradiflik zâil olur. "Siyah" ve "beyaz" kelimeleri alındıktan sonra, "kara" ve "ak" kelimeleri de dilde tutunmuştur. Ama bunlar eş anlamlı kabul edilemez. Çünkü "Halk siyahla beyazı maddiyâtta, kara ile akı maneviyâtta kullanıyor. Meselâ siyah yüzlü bir adamın alnı ak olabilir, beyaz çehreli bir adamın da yüzü kara çıabilir.” (Gökalp, 1996: 115).

İşte bu durum yabancı bir dilden dilimize geçmiş ama acı kelimesiyle tam eş anlamlı sayılamayacak keder ve ızdırap kelimeleri için de geçerlidir. Çünkü “...her mananın yalnız bir kelimesi olmalıdır” (Gökalp, 2017: 127-130). Keder kelimesinin ifade alanında mutsuzluk duygusu daha yoğundur. Izdirap daha derinden hissedilen bir duygudur. Bu durumda GTS'de verilen keder çekmek deyiminin acı duymak, ızdırap çekmek anlamları tek bir maddede değil ayrı maddelerde verilmelidir. Sözlüksel ve eş dizimsel benzerlik acı, ızdırap ve keder kelimelerini birinci dereceden yakın eş anlamlı sınıfına dâhil etmektedir. Ayrıca eğer keder çekmek eşittir acı duymak ise keder çekmek deyiminin bir de ağrı, sızı duymak diye bir anlamı da bulunmalıdır. Ama bu durum keder çekmek deyiminin kullanım sahası dışındadır. Çünkü ağrı, sızı duymak fiziksel bir acıyı da ifade eder. Oysa keder çekmek deyiminde fiziksel bir ağrı durumu bulunmamaktadır.

Keder vermek deyiminin anlamları arasında üzüntü vermek de bulunmaktadır. Ayrıca keder maddesinde de üzüntü anlamı bulunmaktadır. Ama GTS'de üzüntü maddesinde keder anlamı bulunmamaktadır. Bu yakın eş anlamlı kelimeler arasında bir boşluk meydana getirdiğinden üzüntü maddesine de keder ifadesi de eklenmelidir. Üzüntü ve keder kelimeleri sözlüksel yakınlığı bulunan ama eş dizimsel yapı açısından ayrılan kelimeler olduğu için bu kelimeler ikinci dereceden yakın eş anlamlı kelimeler sınıfında yer almaktadır.

Tablo 5: Elem kelimesinin GTS'deki anlam sıralaması: 
Acı maddesinin anlam kapsamında bulunan elem ifadesi incelendiğinde GTS'de elem maddesinin şöyle ele alındığı görülmektedir:

\begin{tabular}{|l|l|l|}
\hline Elem (Arapça) & 1. & Acı, üzüntü, dert, keder. (isim) \\
\hline
\end{tabular}

Elem maddesinin anlamları GTS'de bir maddede sunulmuştur. Elem maddesinin ilk anlamında acı ifadesi yer alırken acı maddesinin dördüncü anlamında elem ifadesi yer almaktadır. Elem maddesinde üzüntü, dert ve keder ifadeleri de bulunmaktadır. Fakat üzüntü, dert ve keder maddelerinde elem ifadesi bulunmamaktadır. Uygunluk analizine göre acı maddesinin dördüncü anlamında bu ifadelerin gramer sınırında isim ve mecaz olarak kullanım sahasına sahip olduğu görülmektedir. Elem maddesinin gramer sınırında bu durum sadece isim olarak nitelendirilmiştir. Maddenin gramer sınırına mecaz da eklenmelidir. Elem kelimesinin anlam sınırında ağrı, sızı da bulunmaktadır. GTS'de bir maddede toplanan bu kelime iki ayrı maddede anlam bulmalıdır: 1. Ağrı, sızı. 2. Üzüntü, acı, dert, keder. Elem kelimesinin fiziksel bir ağrı ile de ilişkisi de vardır. Üzüntü ve acı kelimelerinde yer alan mutsuzluk duygusunun daha yoğun hissiyatı elem kelimesinin anlam sınırındadır. Bu kelimeler birinci dereceden yakın eş anlamlı kelimelerdendir. Ayrıca GTS'de elem çekmek deyimine yer verilmemiştir. Bu deyim de GTS'ye eklenmelidir.

Şekil 1: Acı maddesi ve bu maddenin anlam alanında yer alan ızdırap, üzüntü, keder ve elem kelimelerinin anlam alan işaretleyicileri ${ }^{4}$

1. Acı kelimesinin sözlüksel kavram çizgisi

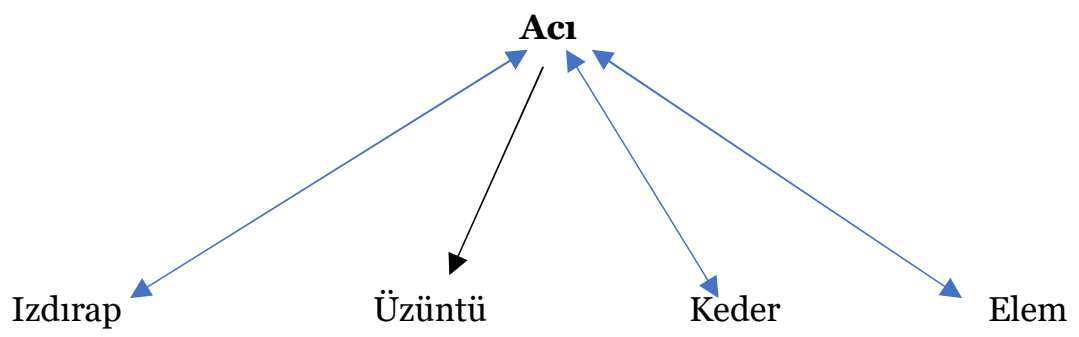

2. Izdırap kelimesinin sözlüksel kavram çizgisi

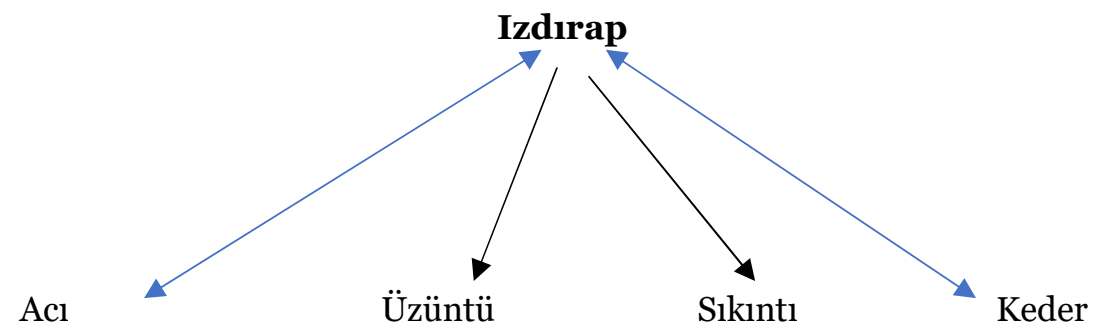

3.Üzüntü kelimesinin sözlüksel kavram çizgisi

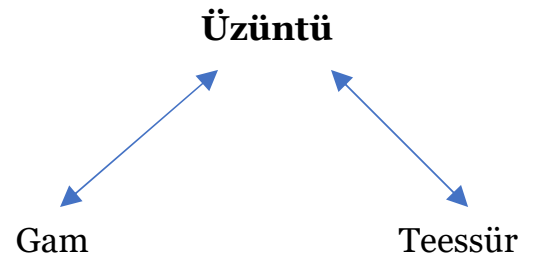

\footnotetext{
$4 \quad$ Çift yönlü mavi işaretleyicisi her iki dil biriminde de aynı anlamın olduğunu, tek yönlü siyah işaretleyicisi ise sadece bir dil biriminde o anlamın olduğunu göstermektedir. Bu işaretleme incelenen kelimelerin GTS'deki anlam kapsamına göre yapılmıştır.
} 
4. Keder kelimesinin sözlüksel kavram çizgisi

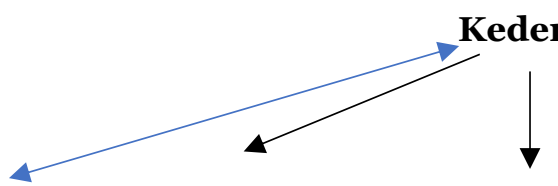

Ac1

Dert

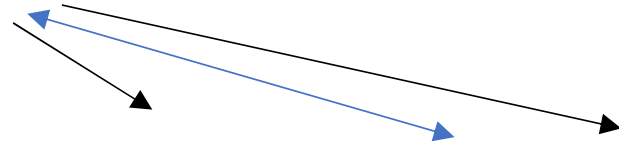

Sikıntı

Izdirap

Tasa

5. Elem kelimesinin sözlüksel kavram çizgisi

\section{Elem}

Acl

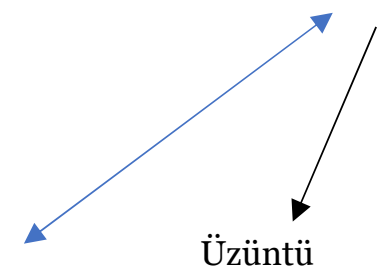

Üzüntü

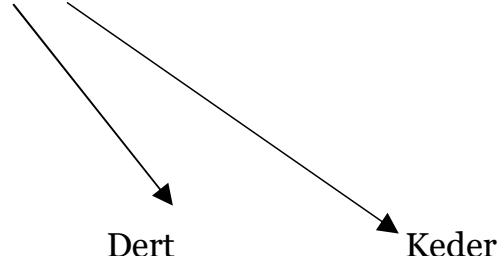

Dert

Keder

\section{Acı Maddesi bağlamında ızdırap, üzüntü, keder ve elem kelimelerinin eş anlamlılık dereceleri}

Tablo 6: Sıkıntı kelimesinin GTS'deki anlam sıralaması:

Acı maddesi bağlamında incelenen ızdırap maddesinin anlam sınırında yer alan sıkıntı kelimesinin GTS'de beş anlamı yer almaktadır. GTS'de sıkıntı maddesinin anlamları şöyle sıralanmaktadır:

\begin{tabular}{|l|l|l|}
\hline \multirow{4}{*}{ Sıkıntı } & 1. & $\begin{array}{l}\text { İsssizlik, tekdüzelik, bezginlik vb. sebeplerden doğan ruhsal yorgunluk, cefa, } \\
\text { eziyet. (isim) }\end{array}$ \\
\cline { 2 - 3 } & 2. & $\begin{array}{l}\text { Bir bozukluğun, karışıllı̆̆ın sebep olduğu etkili ve sürekli yorgunluk, mihnet } \\
\text { (isim) }\end{array}$ \\
\cline { 2 - 3 } & 3. & Yokluk ve parasızlığın yol açtığı geçim darlığı. (isim) \\
\cline { 2 - 3 } & $4 \cdot$ & Bulunmama durumu. (isim) \\
\cline { 2 - 3 } & 5. & Sorun, mesele, sendrom, problem. (isim / mecaz) \\
\hline
\end{tabular}

Izdırap maddesinin anlam sınırında sıkıntı yer almasına rağmen sıkıntı maddesinde ızdırap anlamı bulunmamaktadır5. Izdırap ve sıkıntı kelimeleri ikinci dereceden yakın eş anlamlı kelimelerdir. Her iki kelime anlam açısından değerlendirildiklerinde anlamın iç dinamizmini yani özünü büyük ölçüde paylaşmaktadırlar. Fakat ızdırap kelimesinin iç dinamizminde sıkıntı daha çok yer tutmaktadır.

Sıkıntı maddesinin cefa anlamı birinci sıradayken cefa maddesinin anlamları arasında sıkıntı ifadesi bulunmamaktadır. Cefa maddesine sıkıntı anlamı eklenmelidir. Sıkıntı maddesinin eziyet anlamı birinci sıradadır. Eziyet maddesinde de sıkıntı anlamı birinci sıradadır. Her iki kelime de eş anlam çizgisi ve sınırı açısından aynı düzlemdedir. Sıkıntı maddesinin sorun anlamı bu maddenin beșinci sırasındadır. Sorun maddesinde ise sıkıntı veren durum olarak maddenin ikinci anlamında yer almaktadır. Sıkıntı maddesinin mesele anlamı beşinci sıradadır. Mesele maddesinde sıkıntı anlamı yer almamaktadır. Mesele maddesine sıkıntı anlamı eklenmelidir. Sıkıntı maddesinin beşinci anlamında yer alan sendrom ifadesi, sendrom maddesinin sorun anlamı ikinci sırada yer almaktadır. Sıkıntı maddesinin beşinci anlamında problem ifadesi yer alırken problem maddesinin anlam sınırında sıkıntı bulunmamaktadır. Sıkıntı anlamı problem maddesine eklenmelidir. 


\section{Sıkıntı kelimesinin deyimlerdeki kullanımı:}

Sıkentı basmak: Çok sıkılmak, can sıkıntısı duymak.

Sikıntr çekmek: Zorluk veya yoksulluk içinde yaşamak:

Sıkmt vermek: Tedirgin etmek, bunaltmak.

Sıkıntıda olmak: Geçim darlı̆̆ çekmek.

Sıkıntısı olmak: 1. Tedirgin, rahatsız eden bir durumda bulunmak. 2. İşemesi gerekmek, sıkışmak.

Srkmtnya düşmek: Darlık, yokluk içinde olmak.

Sıkıntıya gelememek: Güç işlere dayanamamak.

Sıkıntı kelimesinin yer aldığı bu deyimlerde görüldüğü üzere ızdırap kavramı bulunmamaktadır. Izdırap olumsuz hissiyatın derecesi açısından daha derin hissedilir. Sıkıntı ise daha geçicidir. Ama ızdırap sıkıntıyı da içinde barındırmaktadır. Sıkıntının en üst dereceden hissedileni ızdırap hissiyatına yaklaşmaktadır. Sıkıntı hissiyatında ızdırap bulunmamaktadır. Sıkıntı kelimesinin kavram dünyasında ruhsal bir gerilim söz konusu iken ızdırapta bu gerilim üst derecededir. Her iki kelime arasındaki fark kavramsal farklılıkta gizlidir.

Tablo 7: Gam kelimesinin GTS'deki anlam sıralaması:

Acı maddesi bağlamında incelenen üzüntü maddesinin anlam sinırında yer alan gam kelimesinin GTS'de bir anlamı yer almaktadır. GTS'de gam maddesinin anlamları şöyle sıralanmaktadır:

\begin{tabular}{|l|l|l|l} 
Gam (Arapça) & 1. & Tasa, kayg, üzüntü. (isim)
\end{tabular}

Gam maddesinin anlam düzlemi GTS'de tek çizgide sunulmuştur. ${ }^{6}$ Acı maddesinin anlam dünyasında yer alan üzüntü maddesi GTS'de oldukça farklı anlamlandırılmıştır. Acı maddesine bağlı olarak ızdırap ve elem maddelerinin iç dinamizminde yer alan üzüntü maddesi incelendiğinde bu madde gam ve teessür ile açıklanmıştır. Bu durum üzüntü kelimesinde acı, ızdırap veya elem duygularının yer alıp almadığı merakını uyandırmaktadır. Gam kelimesinin kullanıldığı deyimlere bakılınca bu deyimlerin madde başı anlamları ile paralel oldukları görülmektedir:

Gam çekmek: Tasalanmak, kaygılanmak, üzülmek.

Gam yememek: Tasa etmemek, kaygılanmamak, üzülmemek.

Üzüntü kelimesi ile ilgili GTS'de sadece bir tane deyim verilmiştir bu deyim incelendiğinde deyimin kavram alanında gam ifadesinin olmadığı görülmektedir:

Üzüntü vermek: Tedirginlik yaratmak, sıkıntı ve huzursuzluğa yol açmak.

Gam maddesinin ilk anlamında yer alan tasa, kaygı ve üzüntü ifadeleri yer almaktadır aynı şekilde tasa, kaygı ve üzüntü maddelerinde de gam ifadesi yer almaktadır. 
Bu deyimde yer alan tedirginlik yaratmak anlamı üzüntü vermek deyimini kısmi olarak kapsamadığı görülmektedir. Çünkü tedirginlik, düşünce veya kaygı duyguları üzüntü duygusu ile benzer veya yakın değildir. Tedirgin olma durumunun sonucunda üzüntü duygusu ortaya çıkabilmektedir. Gam ifadesine geçilecek olursa gam ve üzüntü kelimeleri birinci dereceden yakın eş anlamlı kelimeler sınıfında yer almaktadır. Hem sözlüksel açıdan birbirlerini tamamlamaları hem de gönderimsel bir boşluğa yer vermemeleri bu durumu kuvvetlendirir. Yalnız üzüntü kelimesinin anlam alanında ızdırap, elem, acı duyguları da bulunmaktadır. Bu üç olumsuz duygunun üzüntü ile doğrudan bir ilişkisi bulunmaktadır.

Tablo 8: Teessür kelimesinin GTS'deki anlam sıralaması:

Acı maddesi bağlamında incelenen üzüntü maddesinin anlam sınırında yer alan teessür kelimesinin GTS'de iki anlamı yer almaktadır. GTS'de teessür maddesinin anlamları şöyle sıralanmaktadır:

\begin{tabular}{|l|l|l|}
\hline \multirow{2}{*}{$\begin{array}{l}\text { Teessür } \\
\text { (Arapça) }\end{array}$} & 1. & Üzüntü. (isim) \\
\cline { 2 - 3 } & 2. & Duygulanım. (isim) \\
\hline
\end{tabular}

Üzüntü ile teessür kelimeleri hem sözlük hem kavramsal açıdan benzerlik göstermektedir. Teessür kelimesinin kullanıldığı deyimlere bakılınca bu deyimlerin madde başı anlamları ile paralel oldukları görülmektedir:

Teessür etmek: Üzülmek, acımak.

Teessür göstermek: Üzüntüsünü açı̆̆a vurmak.

Teessür ve üzüntü kelimeleri birinci dereceden yakın eş anlamlı kelimeler sınıfında yer almaktadır. Hem sözlüksel açıdan birbirlerini tamamlamaları hem de gönderimsel bir boşluğa yer vermemeleri bu durumu kuvvetlendirir. Ayrıca acı maddesi bağlamında gam ve teessür duyguları da yer almaktadır. Acı kelimesinin anlamları arasına gam ve teessür ifadeleri eklenmelidir.

Tablo 9: Dert kelimesinin GTS'deki anlam siralaması:

Acı maddesi bağlamında incelenen keder ve elem maddelerinin anlam sınırında yer alan dert kelimesinin GTS'de beş anlamı yer almaktadır7. GTS'de dert maddesinin anlamları şöyle siralanmaktadır:

\begin{tabular}{|l|l|l|}
\hline \multirow{5}{*}{ Dert (Farsça) } & 1. & Üzüntü (isim) \\
\cline { 2 - 3 } & 2. & Hastalık (isim) \\
\cline { 2 - 3 } & $3 \cdot$ & Ağrı (isim) \\
\cline { 2 - 3 } & $4 \cdot$ & Sorun, kaygı (isim $/$ mecaz) \\
\cline { 2 - 3 } & $5 \cdot$ & Halk ağzında ur (isim) \\
\hline
\end{tabular}

\footnotetext{
$7 \quad$ Dert maddesinin 2., 3., ve 5. anlamları çalışmanın sınırlılığı dışındadır. Dert maddesinin dördüncü anlamında sorun ifadesi yer alırken, sorun maddesinin ikinci anlamında dert ifadesi yer almaktadır. Dert maddesinin dördüncü anlamında kaygı ifadesi yer alırken, kaygı maddesinde dert anlamı yer almamaktadır.
} 
Dert kelimesinin ilk karşıllğında üzüntü anlamı bulunurken, üzüntü maddesinde dert anlamı bulunmamaktadır. Dert maddesinde keder ve elem anlamlarına da yer verilmemiştir. Ama GTS'de keder ve elem maddelerinde dert anlamına yer verilmiştir.

İçinde bulunulan kötü durumdan ötürü hissedilen olumsuz duygunun sonucunda üzüntü hissiyatı doğmaktadır. Dert daha kapsayıcı bir anlam mekanizmasına sahiptir. Üzüntü derdin içinde yer alan bir parçadır. Bu yüzden üzüntü kelimesi dert kelimesini kapsamaz ama dert kelimesi üzüntü kelimesini kapsar. Keder ve elem kelimeleri dert kelimesine üzüntü kelimesi ile aynı derecede yakındır. Parça bütün ilişkisi kapsamında keder ve elem kelimeleri dert kelimesinin içerisinde üzüntü kelimesi ile aynı alanı kapsamaktadırlar. Dert kelimesinin kullanıldığı atasözlerine ve deyimlere bakılınca bu deyimlerin ilk anlam olan üzüntü kelimesi ile paralel kullanım alanına sahip oldukları görülmektedir:

Derdine yanmak: Kendi durumuna üzülmek.

Derdini çekmek: Üzüntüsüne katlanmak.

Derdini deşmek (veya depreştirmek): Derdini hatırlatıp yeniden üzülmesine yol açmak.

Dert değil: "Önemsemeye, üzülmeye değmez" anlamında kullanılan bir söz.

Dert etmek (veya edinmek): Bir sorunu veya durumu üzüntü konusu yapmak.

$\mathrm{Bu}$ durumda dert ile üzüntü kelimeleri ikinci dereceden yakın eş anlamlı kelimeler sınıfına dâhil olmaktadır. Dert ile sıkıntı kelimelerinin paralel kullanımı da dikkat çekici bir husustur:

Derdi veren devasmn da verir: "Her sıkıntının, üzüntünün bir çaresi vardır" anlamında kullanılan bir söz.

Derdine deva bulmak: Sıkıntıyı çözümlemek, atlatmak, çaresizliği yenmek.

Derdini söylemeyen (veya anlatmayan) derman bulamaz: "İnsan sıkıntısını başkasına açıklayarak giderebilir" anlamında kullanılan bir söz.

\section{Dert kelimesinin yer aldığı birleşik kelimeler}

Başı dertte: Çözülmesi güç, sıkıntılı bir durumda olan.

Boğaz derdi: 1. Geçim için uğraşma. 2. Yemek pişirme, hazırlama sıkıntıları.

Dert küpü: Sorunları, sıkıntıları çok olan kimse.

Dert ortağı: 1. Aynı derdin sıkıntısı içinde bulunanlardan her biri. 2. Bir kimsenin derdini paylaştığı dostu.

Geçim derdi: Geçim sıkıntısı.

Bu durumda GTS'de dert ve sıkıntı kelimeleri paralel bir yapı ve kullanımda yer almaktadır. Dert kelimesinde sıkıntı kavramı bulunmaktadır. Dert maddesine sıkıntı anlamı eklenmelidir. Ama sıkıntı maddesinde dert ifadesinin bulunmaması doğru bir yaklaşımdır. Farsçadan dilimize geçen dert 
kelimesinin sıkıntı ile eş değer tutulması mümkün değildir. Sıkıntı ifadesinde bunalım, yaşanan bir durum neticesinde ortaya çıkabilecek bir gerginlik anlamları daha ağır basmaktadır. Fakat halk ağzındaki kullanım dert ve sıkıntı kelimelerinin aynı deyimde yer almasına sebep olmuştur. Kelimeler yüzyıllar içerisinde kullanıldıkları değişik bağlamlardan dolayı birbirlerine yaklaşabilmektedirler. Bu durum dil birimlerinin çok uzun bir süreyi kapsayan kullanımı sırasında çok anlamlılık veya alt anlamlılık ortaya çımmaktadır. Çok anlamlı veya alt anlamlı kelimeler arasında mecaz ve ima yoluyla kesişmeler, çakışmalar veya geçişmeler görülebilmektedir (Erdem 2004: 160). Geçim derdi ve geçim sıkıntısı deyimleri arasındaki benzer kullanımını mecaz ve ima yoluyla gerçekleşen bir kesişme olarak kabul etmek mümkündür. Fakat geçim derdi eşittir geçim sıkıntısı olarak kabul görmüş dile yerleşmiş olsa da geçim derdi ifadesi bu deyimin anlam alanına uymamaktadır. Dert, geçmesi veya unutulması daha zor bir hissiyattır. Sıkınt, dert ifadesine göre daha geçicidir. Sıkıntı ifadesinde zorluk, dert ifadesinde ızdırap anlamları daha ağır basmaktadır. Nitekim GTS'de 'Geçim sıkıntısı: Geçinmede çekilen güçlük, geçim derdi, geçim zorluğu.' şeklinde verilmiştir. Bu durumda sıkıntı ve dert kelimeleri hem sözlüksel hem eş dizimsel bağlamdaki yakınlık derecelerine göre ikinci dereceden yakın eş anlamlı kelimeler sinıfına girmektedir.

Tablo 1o: Tasa kelimesinin GTS'deki anlam sıralaması:

Acı maddesi bağlamında incelenen keder maddesinin anlam sınırında yer alan tasa kelimesinin GTS'de iki anlamı yer almaktadır. GTS'de tasa maddesinin anlamları şöyle sıralanmaktadır:

\begin{tabular}{|l|l|l|}
\hline \multirow{2}{*}{ Tasa } & 1. & Üzüntülü düşünce durumu, kaygı, endişe, gam. (isim) \\
\cline { 2 - 3 } & 2. & $\begin{array}{l}\text { Tatmin edici olmayan veya tedirgin eden durumların ortaya çımasını } \\
\text { önleyebilmede, güvensizlik içinde bulunulduğunda duyulan tedirgin edici } \\
\text { duygu. (isim) }\end{array}$ \\
\hline
\end{tabular}

Keder maddesinin anlam sinırında yer alan tasa maddesine bakılınca tasa maddesinde keder anlamına GTS'de yer verilmediği görülmektedir. Tasa duygusunun sonucunda oluşma ihtimali yüksek olan keder duygusu tasa maddesine eklenmelidir. GTS'de tasa ile ilgili sunulan deyimlerde de şu şekildedir:

Tasa etmek: Üzülmek, kaygıya kapılmak.

Sözlüksel açıdan yakınlı̆̆ı bulunan bu tasa ve keder kelimelerinin eş dizimsel açıdan yakınlık dereceleri zayıflamaktadır. Çünkü keder çekmek: Acı duymak, zzdırap çekmek olarak anlamlandırılırken, tasa çekmek: Kaygılanmak, üzüntü içinde olmak, üzülmek olarak anlamlandırılmaktadır. Bu açıdan denilebilir ki tasa ve keder kelimeleri ikinci dereceden yakın eş anlamlı kelimeler sınıfında yer almaktadır. Ama üzüntülü düşünce durumu olarak da ifade edilen tasa maddesine doğrudan üzüntü kelimesi de eklenmelidir. Çünkü tasa kelimesinin doğrudan hem kullanım alanında hem de kavram dünyasında üzüntü duygusu yer almaktadır. Ayrıca tasassma düşmek: Derdine düşmek deyimindeki tasa ve dert kelimelerinin yakınlığı dikkat çekmektedir. Ama tasa kelimesi ile dert kelimelerinin yakınlık derecesi tasa ile keder kelimelerinin yakınlık derecesi ile aynıdır. Çünkü derdine düşmek deyimi GTS'de başınm derdine düssmek: başka bir şeyle ilgilenmeyecek kadar sıkıntılı durumda bulunmak olarak verilmiş ve dert kelimesi sıkıntı kelimesi ile açıklanmıştır. Tasa duygusunun sonucunda oluşması yüksek bir ihtimal olan dert duygusu sözlüksel olarak tasa maddesine eklenmelidir. 


\section{Sonuç}

Eş anlamlılık ifadesinde tamamen denklik veya eşitlik yoktur. Bilişsel yani kavramsal anlam eş anlamlılığın odak noktasıdır. Burada yüksek derecede anlamsal ve kavramsal örtüşme gerektirir. İki kelimenin mutlak eş anlamlı olması için hem anlamları hem bağlamları hem de semantik tüm boyutları aynı olmalıdır. Güncel Türkçe Sözlük sınırlılığında ve acı merkezinde ele alınan kelimeler anlamca birbirine yakındır. Ama bu kelimeler yüzde yüz eş anlamlı değildir. Yüzde yüz eş anlamlllık veya mutlak eş anlamllıkta bir dil biriminin diğer dil birimi ile tüm durumlarda birbirinin yerine geçebilmesi durumu olduğu için ele alınan kelimeleri yakın eş anlamlı kategorisinde değerlendirmek gerekmektedir.

İncelenen veriler ışığında kelimelerin birbirlerinin yerine geçebilme durumları ve eş anlamlılık ilişkileri derecelendirilmiştir. Birinci dereceden yakın eş anlamlılıkta sözlüksel ve eş dizimsel örtüşme yer alırken, ikinci dereceden yakın eş anlamlılıkta ya sözlüksel ya da eş dizimsel örtüşme bulunmaktadır. Her iki derecelendirmede de anlamsal örtüşme, oranları farklı olmak kaydıyla, bulunmaktadır.

Acı kelimesi, ızdırap, üzüntü, keder ve elem kelimeleri ile birinci dereceden yakın eş anlamlı kelimeler sınıfında yer alırken sıkıntı, gam, teessür, tasa ve dert kelimeleri ile ikinci dereceden yakın eş anlamlı kelimeler sınıfındadır. Aynı zamanda bu kelimeler kendi içlerinde de (zzdırap kelimesi sıkıntı ile, üzüntü kelimesi keder ile, tasa kelimesi keder ve dert ile, dert kelimesi keder elem, üzüntü ve sıkıntı ile) ikinci dereceden yakın eş anlamlı kelimeler sınıfında yer alırken üzüntü kelimesinin gam ve teessür kelimeleri ile birinci dereceden yakın eş anlamlı sınıfında saymak mümkündür. Ayrıca inceleme ve değerlendirme sonucunda Güncel Türkçe Sözlük'ün madde başlarına eklenmesi gereken bazı noktalar bulunmaktadır: Izdırap çekmek deyimi iki ayrı maddede incelenmelidir. Keder ve elem maddelerinin gramer sınırlarına ismin yanında mecaz kategorisi de eklenmelidir. Elem maddesi iki ayrı maddede anlamlandırılmalıdır. Ayrıca Güncel Türkçe Sözlük'e elem çekmek deyimi ile acı maddesine gam ve teessür; üzüntü maddesine acı ve keder; dert maddesine keder, elem ve sıkıntı; tasa maddesine de dert anlamları eklenmelidir.

\section{Kaynakça}

Aksan, D. (1996). Türkçenin Sözvarlı̆̆l, Ankara: Engin.

Aksan, D. (2006). Anlambilim Anlambilim Konuları ve Türkçenin Anlambilimi, Ankara: Engin.

Cruse, A. D. (1986). Lexical Semantics, Cambridge:Cambridge University Press.

Cruse, A. D. (2000). Meaning in Language: An Introduction to Semantics and Pragmatics, Oxford: Oxford University Press.

Demirezen, M. (1991). “Türkçeye İngilizceden Geçen Sözcükler ve Eş anlamlılık”, Dilbilim Araştırmaları, Ankara: Hitit, s.133-136.

Doğan, N. (2011). "Türkiye Türkçesi Fiillerinde Eş Anlamlılık”, Uluslararası Sosyal Araştırmalar Dergisi, C. 4 , S. 19, s. $78-88$.

Erdem, M. (2004). "Oğuz Grubu Türk Lehçelerinde Eş Anlamlılık (Synonym)”, Zeynep Korkmaz Armağanı, Ankara: TDK, s.147

Firth, J., (1957). Papers in Linguistic, London: Oxford University Press.

Gökalp, Z. (1996). Türkçülüğün Esasları, İstanbul: Kamer.

Guıraud, P. (1999). Anlambilim (Çev: Berke Vardar), İstanbul: Multilingual.

Güncel Türkçe Sözlük, https://sozluk.gov.tr/, 28.05.2020.

Hatipoglu, V., (1970). “Eş anlamlı Sözcükler Var mıdır?”, Türk Dili Dergisi S.229, s. 9-10.

İmer, K., Kocaman A., Özsoy S. (2011). Dilbilim Sözlüğü, İstanbul: Boğaziçi Üniversitesi. 
Karaağaç, G. (2013). Dil Bilimi Terimleri Sözlüğü, Ankara: Türk Dil Kurumu.

Korkmaz, Z. (2007). Gramer Terimleri Sözlüğü, Ankara: Türk Dil Kurumu.

Lyons, J. (1983). Kuramsal Dilbilime Giriş (Çev: Ahmet Kocaman), Ankara: Olgaç.

Murphy, M. L. (2003). Semantic Relations And The Lexicon, Cambridge: Cambridge University Press.

Partington, A. (1998). Patterns and Meaning, Using Corpora for English Language Research and Teaching, Amsterdam/ Philadelphia, John Benjamins Publication Company.

Pilten, Ş. (2008). Türkçede Eş Anlamlılık (Doktora Tezi), Ankara: Ankara Üniversitesi.

Tamba-Mecz, İ. (1998). Anlambilim (Çev: Necmettin Sevil), İstanbul: İletişim.

Ullmann, S. (1959). The Principle Of Semantics, London: Oxford Basil Blackwell.

Vardar, B. (2007). Açıklamalı Dilbilim Terimleri Sözlüğü, İstanbul: Multilingual. 